\title{
EFEKTIFITAS HAND LETTERING SEBAGAI MEDIA PROMOSI KESEHATAN REMAJA MENGENAI BAHAYA ROKOK (STUDI DI SMK PGRI 4 SURABAYA)
}

\author{
Azmi Luthfia ${ }^{1}$, Pulung Siswantara ${ }^{2}$ \\ ${ }^{1,2}$ Departemen Promosi Kesehatan dan Ilmu Perilaku \\ Fakultas Kesehatan Masyarakat Universitas Airlangga \\ Alamat Korespondensi: Azmi Luthfia \\ Email: azmiluthfia93@gmail.com
}

\begin{abstract}
Indonesia is a country with largest smoker in South East Asia. According to Riset Kesehatan Dasar (RISKESDAS) (2013), there is rising trends of cigarette smooking during three periods, especially in adolescents aged $\geq 15$ years. Therefore it is necessary to take effort to prevent existence of it. Providing health promotion media in the form of hand lettering can be an alternative in providing effective information and education. Now days, Hand lettering is a popular art design for adolescents. This research was conducted on the students of class XI TKR SMK PGRI 4 Surabaya. The purpose of this study was to know the efectiveness of hand lettering as a health promotion media of harmfull effect of cigarettes in adolescents. It was quasi experimental research. Samples are 90 students of class XI TKR SMK PGRI 4 Surabaya, taken by total sampling technique. Knowledge was dependent variable, while giving treatments was independent variables. Results showed that there were differences knowledge betwween before and after hand lettering given ( $p=0,000)$. Media effectiveness shows that hand lettering is effective for improving knowledge. It can be used as a health promotion media of harmfull effect of cigarettes in adolescents.
\end{abstract}

Keywords: hand lettering, health promotion media, harmfull effect of cigarettes

\begin{abstract}
ABSTRAK
Indonesia, negara dengan presentase jumlah perokok terbesar di Asia Tenggara. Data Riset Kesehatan Dasar (Riskesdas) (2013) menunjukkan peningkatan prevalensi merokok selama 3 periode. Peningkatan terbanyak berada pada remaja usia 15 tahun keatas. Oleh karena itu dibutuhkan upaya promosi kesehatan untuk mencegah terjadinya hal tersebut. Pemberian media promosi kesehatan berupa hand lettering dapat menjadi alternatif untuk memberikan informasi dan edukasi. Saat ini hand lettering merupakan seni yang sedang populer di kalangan remaja. Penelitian ini dilakukan pada siswa kelas XI TKR SMK PGRI 4 Surabaya. Tujuan penelitian ini untuk mengetahui efektifitas hand lettering sebagai media promosi kesehatan mengenai bahaya rokok pada remaja. Metode penelitian yang digunakan adalah eksperimental semu dengan rancangan pre test - post test group design. Jumlah sampel adalah 90 siswa yang dibagi menjadi 3 kelompok. Sampel diambil berdasarkan teknik total populasi. Varibel bebas dalam penelitian ini adalah pemberian perlakuan dengan media hand lettering dan poster, sedangkan variabel terikat adalah pengetahuan dan sikap. Hasil penelitian menunjukan terdapat perbedaan pengetahuan sebelum dan sesudah diberikan hand lettering $(p=0,000)$. Efektifitas media menunjukkan bahwa hand lettering efektif meningkatkan pengetahuan responden. Kesimpulan penelitian ini adalah hand lettering efektif digunakan sebagai media promosi kesehatan bahaya rokok pada remaja.
\end{abstract}

Kata kunci: hand lettering, media promosi kesehatan, bahaya rokok

\section{PENDAHULUAN}

Rokok menjadi salah satu penyebab terbesar kematian yang dapat dicegah di masyarakat. Akibat yang dapat ditimbulkan tidak hanya bagi perokok sendiri (perokok aktif) namun juga pada orang yang ikut menghirup asapnya yang disebut dengan perokok pasif. Selain berdampak pada masalah kesehatan, merokok juga dapat berdampak pada sosial, ekonomi dan lingkungan. Rokok menjadi faktor risiko kejadian berbagai penyakit kronis yang mematikan, seperti kanker, penyakit paru-paru dan penyakit kardiovaskuler (WHO, 2013). Risiko 
tersebut muncul akibat zat kimia yang terkandung di dalamnya seperti nikotin dan karbon monoksida serta racun-racun lainnya yang dihisap dan masuk ke dalam tubuh. Jika jumlah konsumsi rokok semakin meningkat maka akan berdampak pada semakin tingginya angka morbiditas dan mortalitas akibat rokok.

Berdasarkan data yang diperoleh dari Infodatin (2013), pada tahun 2030 diperkirakan angka kematian akibat rokok di dunia akan semakin bertambah hingga mencapai 10 juta jiwa. Angka kematian tersebut sebagian besar berasal dari negara berkembang. Terdapat 1,2 milyar perokok di dunia dan 800 juta di antaranya berada di negara berkembang. Terdapat lebih dari separuh penduduk Asia dan Australia yang mengonsumsi rokok yaitu 57\%. Indonesia merupakan negara dengan presentase jumlah perokok terbesar di Asia Tenggara yaitu sebanyak 46,16\%.

Data Riskesdas tahun 2013 menyebutkan bahwa sebagian besar perokok di Indonesia merupakan penduduk laki-laki. Terdapat peningkatan perilaku merokok selama tiga periode berturut-urut, terutama pada penduduk umur diatas 15 tahun. Pada tahun 2007 terdapat 34,2\%, tahun 2010 meningkat menjadi 34,7\%, dan tahun 2013 meningkat menjadi 36,3\%. Tren peningkatan usia mulai merokok tertinggi dan terbanyak berada pada usia 15 - 19 tahun. Hal ini menunjukkan tren merokok di Indonesia didominasi oleh remaja (Riskesdas, 2013).

WHO menyebutkan bahwa remaja merupakan masa peralihan dari kanak-kanak menuju dewasa. Batasan usia remaja adalah 12-24 tahun. Kementrian Kesehatan RI tahun 2010, batas usia remaja yaitu antara 10-19 tahun dan belum menikah. Pada masa remaja terjadi pertumbuhan dan perkembangan yang pesat baik secara fisik, psikologis, maupun intelektual. Remaja memiliki sifat khas yaitu rasa keingintahuan yang besar, ingin mencoba hal baru, lebih senang berkumpul bersama teman- temannya, mudah terpengaruh oleh lingkungannya, seta berani menanggung risiko atas perbuatannya tanpa didahului oleh pertimbangan yang matang (BKKBN, 2009). Apabila keputusan yang diambil tidak tepat dapat menjerumuskan ke dalam perilaku yang tidak sehat. Salah satunya adalah perilaku merokok. Berdasarkan data Ikatan Ahli Kesehatan Masyarakat Indonesia (IAKMI), pada tahun 2015 terdapat 2.839.115 jiwa jumlah perokok anak-anak dan remaja di Jawa Timur dari total 3.094.028 jiwa, dan 46\% dari perokok tersebut berumur 15-19 tahun.

Surabaya merupakan salah satu kota besar yang berada di Jawa Timur, sehingga tidak menutup kemungkinan bahwa remaja di Surabaya juga berisiko terhadap perilaku merokok. Remaja usia 15-19 tahun merupakan remaja yang sedang menduduki Sekolah Menengah Atas (SMA) ataupun yang sederajat. Sekolah Menengah Kejuruan (SMK) PGRI 4 Surabaya adalah salah satu sekolah swasta setingkat SMA yang terdapat di Kota Surabaya. Berdasarkan hasil studi pendahuluan menyebutkan sebagian besar siswa-siswi yang berada di sekolah ini berasal dari keluarga dengan tingkat ekonomi menengah ke bawah. Marmot dan Wilkinson (2006) menyebutkan bahwa tingkat ekonomi merupakan determinan sosial kesehatan yang mengarah pada perilaku berisiko seperti merokok. Semakin rendah tingkat ekonomi seseorang semakin rentan terjerumus perilaku merokok. Sebagian besar siswa di sekolah ini berusia 15-19 tahun. Usia tersebut merupakan usia rawan bagi remaja untuk mencoba hal baru termasuk perilaku merokok. Saat ini pihak sekolah telah melakukan upaya pencegahan perilaku merokok di kalangan remaja melalui materi yang disampaikan oleh guru. Namun sayangnya masih terdapat siswa yang mencoba perilaku tersebut setelah keluar dari lingkungan sekolah. Oleh karena itu perlu dilakukan alternatif lain sebagai upaya pencegahan agar remaja 
tidak terjerumus kedalam perilaku berisiko seperti merokok.

Promosi kesehatan merupakan salah satu upaya untuk meningkatkan kesehatan masyarakat yang berfokus pada upaya promotif dan preventif. Upaya ini bertujuan untuk mengubah perilaku masyarakat agar mampu menjaga dan meningkatkan derajat kesehatannya secara mandiri (Ottawa Charter, 1996 dalam Puspromkes, 2011). Pemberian informasi dan edukasi melaui media merupakan salah satu bentuk promosi kesehatan. Media merupakan alat bantu saluran komunikasi yang bermanfaat untuk mempermudah penyampaian pesan kesehatan pada masyarakat (Notoatmodjo, 2007) Penggunaan media seperti poster dan hand lettering dapat menjadi alternatif untuk menyampaikan informasi kepada masyarakat khususnya remaja.

Penggunaan poster sebagai media promosi kesehatan sudah sering dijumpai. Poster sering digunakan karena tahan lama, pembuatannya murah, memberikan rasa keindahan serta mempermudah pemahaman. Namun pemelitian yang dilakukan oleh Kusuma (2014) menyebutkan bahwa efektifitas poster pada remaja saat ini berkurang dibandingkan media lain. Penggunaan hand lettering sebagai media promosi kesehatan masih jarang dilakukan. Sebenarnya karya ini sudah muncul sejak puluhan tahun yang lalu dan sering menghiasi dunia periklanan pada masanya (Alessio, 2013). Saat ini karya hand lettering kembali menjadi trend terutama di kalangan anak muda dan remaja. Karya ini merupakan sebuah media komunikasi untuk menyampaikan pesan melalui seni menggambar atau mempercantik huruf. Menurut Keesee (2017), sejak 3 tahun terakhir karya yang pada zaman dahulu pernah populer ini, sekarang kembali diminati karena desainnya yang simple dan kreatif. Hal itu dibuktikan dengan munculnya beberapa akun sosial media yang memuat konten hand lettering baik dari dalam negeri maupun luar negeri. Selain itu karya yang saat ini sudah banyak diinovasi dengan berbagai ornamen modern tersebut sering menghiasi tempat berkumpulnya anak muda seperti cafe, kedai-kedai makanan, dan toko yang sering dikunjungi oleh remaja. Hand lettering dapat dimanfaatkan sebagai media alternatif dan inovatif dalam promosi kesehatan terutama bagi remaja. Telah dibuktikan dari penelitian yang dilakukan oleh Dewi (2016) bahwa hand lettering ekfektif untuk meningkatkan pengetahuan remaja mengenai HIV dan AIDS sehingga perlu dilakukan penelitian untuk mengkaji efektifitas hand lettering terkait bahaya rokok. Tujuan dari penelitian ini adalah untuk mengidentifikasi efektifitas hand lettering sebagai media promosi kesehatan bahaya rokok pada remaja.

\section{METODE PENELITIAN}

Metode penelitian yang digunakan dalam penelitian ini adalah metode kuantitatif dengan pendekatan eksperimental semu. Rancangan penelitian yang digunakan adalah pre - post test group design. Responden dibagi menjadi 3 kelompok yaitu 2 kelompok perlakuan dan 1 kelompok kontrol. Sebelum diberikan perlakuan, ketiga kelompok ini diberikan pre-test kemudian diberikan intervensi. Intervensi yang diberikan berupa media poster pada kelompok perlakuan I dan hand lettering pada kelompok perlakuan II. Kelompok kontrol tidak diberikan perlakuan. Media poster yang digunakan dalam penelitian ini didapatkan dari bagian promosi kesehatan kementrian kesehatan. Hand lettering merupakan transformasi dari poster tersebut. Pemberian intervensi dilakukan selama 15 menit. Setelah diberikan perlakuan responden diberikan kuesioner post-test.

Populasi yang digunakan dalam penelitian ini adalah siswa - siswi kelas XI jururan Teknik Kendaraan Ringan (TKR) di SMK PGRI 4 Surabaya. Jumlah populasi adalah 108 siswa dan seluruhnya berjenis kelamin laki-laki. Sample diambil 
berdasarkan teknik total populasi dan ditemukan responden sebanyak 90 anak yang memenuhi kriteria inklusi. Tiap kelas terdiri dari 30 siswa. Kriteria inklusi dalam penelitian ini adalah siswa yang mendapatkan persetujuan orang tua untuk ikut serta dalam penelitian ini, dan hadir pada saat penelitian. Pengambilan data dilakukan pada bulan Oktober 2017. Variabel bebas pada penelitian ini adalah perlakuan yang diberikan, sedangkan variabel terikat adalah pengetahuan responden.

Pengkajian efektifitas hand lettering dilakukan dengan menganalisis adanya perubahan nilai pengetahuan dari hasil pre-test dan post-test pada tiap kelompok.

Uji statistik penelitian ini menggunakan Uji $t$ berpasangan untuk melihat perbedaan sebelum dan setelah diberikan perlakuan dan Uji t sampel bebas untuk melihat perbedaan antar kelompok.

\section{HASIL}

\section{Karakteristik Responden}

Jumlah responden yang memenuhi kriteria inklusi pada penelitian ini adalah 90 siswa yang terbagi menjadi 3 kelompok. Pada tiap kelas terdapat 30 responden. Karakteristik umur responden dapat dilihat pada tabel 1.

Tabel 1. Karakteristik Responden

\begin{tabular}{ccc}
\hline $\begin{array}{c}\text { Usia } \\
\text { Responden } \\
\text { (tahun) }\end{array}$ & Frekuensi & Persentase \\
\hline \multicolumn{3}{c}{ Kelompok Poster } \\
\hline $15-16$ & 21 & 70 \\
\hline $17-18$ & 9 & 30 \\
\hline Total & 30 & 100 \\
\hline \multicolumn{3}{c}{ Kelompok Hand Lettering } \\
\hline $15-16$ & 17 & 57 \\
\hline $17-18$ & 13 & 43 \\
\hline Total & 30 & 100 \\
\hline \multicolumn{3}{c}{ Kelompok Kontrol } \\
\hline $15-16$ & 17 & 57 \\
\hline $17-18$ & 13 & 43 \\
\hline Total & 30 & 100 \\
\hline
\end{tabular}

Berdasarkan Tabel 1 dapat diketahui bahwa responden yaitu siwa kelas XI TKR SMK PGRI 4 Surabaya berusia 15 hingga 18 tahun. Rata-rata usia usia responden antara ketiga kelompok adalah 15-16 tahun. Hasil penelitian diketahui bahwa seluruh responden yaitu siswa kelas XI TKR SMK PGRI 4 Surabaya memiliki jenis kelamin laki-laki.

\section{Pengetahuan Responden Sebelum dan Sesudah Diberikan Poster}

Tingkat pengetahuan responden sebelum dan sesudah diberikan poster diukur dengan menggunakan kuesioner pre - post-test. Kemudian hasil tersebut diUji menggunakan Uji $\mathrm{t}$ berpasangan untuk melihat adakah perbedaan antara sebelum dan sesudah diberikan media poster. Sebelum dilakukan pengukuran terlebih dahulu dilakukan Uji normalitas data pada kedua variabel. Uji normalitas data menunjukan bahwa variabel pre-test dan post-test berdistribusi normal. Setelah diUji menggunakan Uji $\mathrm{t}$ berpasangan diperoleh nilai signifikansi $\mathrm{p}$ sebesar 0,72 yang berarti nilai $\mathrm{p}$ lebih dari $\alpha(0,05)$ sehingga dapat dikatakan bahwa tidak ada perbedaan yang signifikan antara sebelum dan sesudah diberikan media poster. Ratarata pengetahuan responden menganai bahaya rokok pada kelompok poster sebelum dan sesudah diberikan perlakuan dapat dilihat pada Tabel 2 .

Tabel 2. Rata-rata Pengetahuan Responden pada Media Poster Sebelum dan Sesudah Perlakuan

\begin{tabular}{cccc}
\hline Nilai & Rata-rata & p value & n \\
\cline { 1 - 2 } Sebelum & 56,13 & \multirow{2}{*}{0,072} & \multirow{2}{*}{30} \\
\cline { 1 - 2 } Sesudah & 59,60 & & \\
\hline
\end{tabular}

Berdasarkan Tabel 2 dapat diketahui bahwa terdapat peningkatan pengetahuan responden sebelum dan sesudah diberikan media poster. Walaupun demikian hasil kuesioner menunjukkan bahwa masih terdapat $47 \%$ responden tidak 
menjawab pertanyaan mengenai kandungan berbahaya di dalam rokok dengan benar setelah diberikan poster. Sebagian besar responden pada kelompok ini belum mengetahui bahwa di dalam rokok juga terkandung zat berbahaya yang biasa digunakan pada racun tikus, bahan pembuatan baterai, dan pestisida. Sementara itu hasil kuesioner mengenai bahaya rokok bagi kesehatan menunjukkan bahwa $32,8 \%$ responden tidak menjawab dengan benar. Sebagian besar responden belum mengetahui bahwa rokok juga dapat menyebabkan penyakit seperti bercak merah, berair, dan gatal yang disebut dengan psoriasis.

\section{Pengetahuan Responden Sebelum dan Sesudah Diberikan Hand Lettering}

Pada kelompok ini perlakuan yang diberikan berupa pemberian media hand lettering mengenai bahaya rokok. Responden pada kelompok hand lettering juga diberikan kuesioner pre-test dan posttest untuk melihat adakah perbedaan tingkat pengetahuan responden antara sebelum dan sesudah diberikan media hand lettering. Setelah dilakukan Uji normalitas data, diperoleh hasil bahwa data berdistribusi normal sehingga dapat dilakulan Uji $\mathrm{t}$ berpasangan. Hasil Uji tersebut menunnjukkan nilai signifikansi $\mathrm{p}$ kurang dari $\alpha(0,05)$ yaitu sebesar 0,000 sehingga dapat dikatakan terdapat perbedaan pengetahuan antara sebelum dan sesudah diberikan media hand lettering. Rata-rata pengetahuan responden mengenai bahaya rokok pada kelompok hand lettering sebelum dan sesudah diberikan perlakuan dapat dilihat pada Tabel 3.

Tabel 3. Rata-rata Pengetahuan Responden pada Media Hand Lettering Sebelum dan Sesudah Perlakuan

\begin{tabular}{cccc}
\hline Nilai & Rata-rata & p value & n \\
\cline { 1 - 2 } Sebelum & 54,93 & \multirow{2}{*}{0,000} & \multirow{2}{*}{30} \\
\cline { 1 - 2 } Sesudah & 67,87 & & \\
\hline
\end{tabular}

Tabel 3 menunjukkan terjadinya peningkatan pengetahuan pada responden pada kelompok hand lettering berdasarkan nilai rata-rata sebelum dan setelah diberikan perlakuan. Berdasarkan hasil kuesioner masih terdapat 38\% responden tidak menjawab dengan benar terkait pertanyaan mengenai kandungan bahan berbahaya di dalam rokok, setelah diberikan hand lettering. Sebagian besar responden pada kelompok ini belum mengetahui bahwa di dalam rokok juga terkandung zat berbahaya seperti geranol yang biasanya digunakan sebagai pestisida. Sementara itu hasil kuesioner mengenai bahaya rokok bagi kesehatan menunjukkan bahwa $32 \%$ responden tidak menjawab dengan benar. Seperti halnya pada kelompok poster, sebagian besar responden pada kelompok ini juga belum mengetahui bahwa rokok dapat menimbulkan penyakit psoriasis.

\section{Pengetahuan Responden Pada Kelompok Kontrol}

Pada kelompok kontrol, responden tetap diberikan kuesioner pre-test dan posttest untuk mengetahui adakah perubahan tingkat pengetahuan responden. Hasil Uji normalitas menunjukan bahwa data berdistribusi normal sehingga dapat dilakukan Uji t berpasangan. Hasil Uji t menunjukkan nilai signifikansi $p$ adalah 1,000. Nilai tersebut lebih besar dari $\alpha$ $(0,05)$ sehingga dapat dikatakan bahwa tidak ada perbedaan antara pre-test dan post-test pada kelompok kontrol. Rata-rata pengetahuan responden menganai bahaya rokok pada kelompok kontrol sebelum dan sesudah diberikan perlakuan dapat dilihat pada Tabel 4.

Tabel 4. Rata-rata Pengetahuan Responden pada Kelompok Kontrol Sebelum dan Sesudah Perlakuan

\begin{tabular}{cccc}
\hline Nilai & Rata-rata & p value & n \\
\cline { 1 - 2 } Sebelum & 54,80 & \multirow{2}{*}{1,000} & \multirow{2}{*}{30} \\
\cline { 1 - 2 } Sesudah & 54,80 & & \\
\hline
\end{tabular}


Tabel 4 menunjukkan tidak ada perbedaan nilai rata-rata pada kelompok kontrol. Hasil kuesioner pada kelompok ini menunjukkan bahwa sebagian besar responden (65\%) tidak menjawab pertanyaan mengenai kandungan berbahaya di dalam rokok dengan benar. Sebagian besar responden pada kelompok ini belum mengetahui bahwa di dalam rokok juga terkandung zat berbahaya yang biasanya digunakan sebagai bahan pestisida, baterai, dan racun tikus. Sementara itu hasil kuesioner mengenai bahaya rokok bagi kesehatan menunjukkan bahwa 49\% responden tidak menjawab dengan benar. Sebagian besar responden belum mengetahui bahwa rokok dapat menimbulkan karies pada gigi dan menyebabkan osteoporosis serta hilangnya pendengaran.

\section{Perbedaan Antara Kelompok Poster, Hand Lettering, dan Kelompok Kontrol}

Perbedaan antar kelompok pada penelitian ini dianalisis berdasarkan hasil Uji statistik menggunakan Uji t dua sample bebas. Pertama, Uji t dilakukan dengan membandingkan antara kelompok poster dan kelompok kontrol. Kedua, kelompok hand lettering dengan kelompok kontrol. Ketiga, antara kelompok poster dan hand lettering.

Sebelum dilakukan Uji $t$ dua sample bebas, data pre-test dan post-test terlebih dahulu dilakukan Uji normalitas dan pada pre - test. Berdasarkan Uji normalitas diperoleh bahwa data tersebut berdistribusi nornal. Varians data merupakan varians homogen menurut hasil Lavene's test.

Setelah dilakukan Uji t dua sampel bebas pada kelompok poster dan kelompok kontrol diperoleh nilai signifikansi $p$ adalah 0,059 . Artinya nilai tersebut lebih dari $\alpha(0,05)$. Oleh karena itu dapat dikatakan bahwa secara statistik tidak terdapat perbedaan yang signifikan antara kelompok poster dan kelompok kontrol.
Sementara itu hasil Uji $t$ berpasangan pada kelompok hand lettering dan kelompok kontrol menunjukkan nilai signifikansi $p$ kurang dari $\alpha$. Nilai p pada kelompok ini adalah 0,000 sehingga dapat dikatakan bahwa terdapat perbedaan antara kelompok hand lettering dan kelompok kontrol. Selanjutnya perbandingan antara kelompok poster dan kelompok hand lettering menunjukkan nilai $p=0,04$. Nilai tersebut kurang dari $\alpha$ sehingga dapat dikatakan bahwa terddapat perbedaan antara kelompok poster dan hand lettering.

\section{Efektifitas Media}

Efektifitas media diukur berdasarkan nilai rata-rata pre-test dan post-test pada tiap kelompok. Media dikatakan efektif apabila terdapat peningkatan nilai rata-rata lebih besar sama dengan $10 \%$. Perubahan nilai rata-rata pada tiap kelompok dapat dilihat pada tabel 5 .

Tabel 5. Efektifitas Media Pada Kelompok Poster, Hand Lettering, dan Kontrol

\begin{tabular}{lccc}
\hline Kelompok & $\begin{array}{c}\text { Rata- } \\
\text { rata } \\
\text { Pre-test }\end{array}$ & $\begin{array}{c}\text { Rata- } \\
\text { rata } \\
\text { Post-test }\end{array}$ & $\begin{array}{c}\text { Nilai } \\
\text { Efektif } \\
\text { itas } \\
(\%)\end{array}$ \\
\hline Poster & 56,13 & 59,60 & 6,18 \\
\hline Hand & 54,93 & 67,87 & \\
Lettering & & & 23,56 \\
\hline Kontrol & 54,80 & 54,80 & 0,00 \\
\hline
\end{tabular}

Berdasarkan Tabel 5 dapat dilihat bahwa nilai efektifitas pada kelompok poster dan kontrol kurang dari 10\%, sedangkan pada kelompok hand lettering lebih dari $10 \%$. Oleh karena itu dapat dikatakan bahwa media poster pada penelitian ini kurang efektif untuk meningkatkan pengetahuan responden terkait bahaya rokok, sedangkan media hand lettering efektif untuk meningkatkan pengetahuan respoden terkait bahaya rokok. 
Berdasarkan hasil kuesioner mengenai efektifitas media terdapat responden yang menjawab bahwa ukuran huruf yang terdapat di media poster terlalu kecil dan tulisan yang dimuat kurang jelas. Hal tersebut berbeda dengan tulisan yang tercantum dalam media hand lettering. Oleh karena itu tulisan pada poster sulit dibaca oleh responden. Selain itu walaupun bahasa dan pesan yang disampaikan pada kedua media ini sama, namun menurut responden bahasa yang digunakan pada hand lettering lebih mudah dimengerti sehingga pesan yang disampaikan mudah untuk diterima serta dipahami. Namun terkait warna pada kedua media tersebut, responden kurang menyukai komposisi warna yang digunakan.

\section{PEMBAHASAN}

\section{Karakteristik Responden}

Berdasarkan hasil penelitian diketahui bahwa sebagian besar responden yaitu siswa kelas XI TKR SMK PGRI 4 Surabaya berusia 16 dan 17 tahun. Usia tersebut termasuk dalam kategori usia rentan mulai merokok menurut riskesdas (2013). Selain itu WHO juga menyampaikan bahwa pada usia tersebut termasuk dalam usia remaja. Sebagai remaja responden memiliki kondisi psikis yang masih labil dan mudah dipengaruhi oleh lingkungan sekitar, memiliki rasa ingin tahu yang besar dan senang berkumpul bersama teman-temannya sehingga dapat dimanfaatkan untuk menyebarkan informasi yang positif. Salah satu informasi yang dapat disampaikan kepada remaja adalah informasi mengenai rokok yang mencakup bahan berbahaya yang terkandung di dalam rokok dan bahayanya bagi kesehatan.

\section{Pengetahuan Responden Sebelum dan Sesudah Diberikan Poster}

Pada kelompok yang diberikan perlakuan berupa media poster, nilai pengetahuan responden terbanyak sebelum diberikan perlakuan adalah 60-69 yang termasuk dalam kategori cukup (Nursalam, 2008). Nilai tersebut menunjukan bahwa sebelum diadakannya penelitian ini responden pernah terpapar informasi mengenai bahaya rokok. Hal tersebut sesuai dengan hasil wawancara dengan staf pengajar bahwa siswa di sekolah ini pernah diberikan materi mengenai kenakalan remaja yang di dalamnya mencakup bahaya rokok. Sebagian responden mengatakan pernah merokok karena kemungkinan mereka pernah terpapar oleh kemasan rokok. Paparan bahaya rokok diperoleh remaja dari televisi. Informasi mengenai bahaya rokok juga tercantum pada kemasan rokok hampir setiap hari remaja terpapar televisi karena tidak sedikit iklan di televisi yang menayangkan mengenai hal tersebut. Oleh karena itu remaja memiliki kemudahan akses dalam memperoleh informasi terkait bahaya rokok. Hal tersebut sesuai dengan menyatakan Liviyana (2017) bahwa kemudahan akses informasi mengenai bahaya rokok didapat melalui iklan rokok di televisi dan kemasan rokok, namun kualitas informasi tentang bahaya rokok dirasa masih kurang.

Setelah diberikan perlakuan, tedapat peningkatan pengetahuan pada responden. Peningkatan tersebut menandakan adanya informasi baru yang diperoleh responden setelah mengamati poster bahaya rokok yang diberikan. Setelah diberikan poster responden mengetahui berbagai zat berbahaya yang terkandung di dalam rokok dan bahaya rokok bagi kesehatan sesuai yang tertera di dalam poster tersebut. Notoatmodjo (2007) menyampaikan bahwa pengetahuan merupakan hasil dari tahu setelah orang melakukan penginderaan terhadap objek tertentu. Pada penelitian ini poster berperan sebagai objek yang diamati oleh responden sehingga menghasilkan pengetahuan. Beberapa penelitian sebelumnya juga telah membuktikan bahwa poster dapat meningkatkan 
pengetahuan responden, seperti penelitian yang dilakukan oleh Zuliyani (2016) dan Kusuma (2014). Jika pada penelitian sebelumnya peningkatan pengetahuan terjadi secara signifikan, namun pada penelitian ini tidak demikian sehingga pada saat dilakukan Uji statistik dengan menggunakan Uji t berpasangan diperoleh hasil tidak terdapat perbedaan signifikan antara sebelum dan sesudah diberikan media poster. Walaupun sama-sama menggunakan poster sebagai objek penelitian namun poster yang digunakan dalam penelitian ini berbeda sehingga berbeda pula kemampuan media tersebut untuk meningkatkan pengetahuan. Selain itu sebelum diberikan media poster yang diambil dari promkes depkes tersebut responden telah memiliki pengetahuan yang cukup sehingga kemungkinan mereka pernah terpapar oleh poster yang lebih menarik. Oleh karena itu peningkatan pengetahuan yang terjadi setelah dilakukan intervensi tidak signifikan.

\section{Pengetahuan Responden Sebelum dan Sesudah Diberikan Hand Lettering}

Pada kelompok ini media yang diberikan berupa hand lettering. Hasil kuesioner pre-test menunjukkan sebagian besar responden memiliki nilai pengetahuan kurang yaitu 40-49. Walaupun terdapat kemudahan akses dalam memperoleh informasi kesehatan terkait bahaya rokok melalui tayangan iklan di televisi atau pun kemasan rokok seperti yang dikatakan oleh Liviyana (2017), namun tidak semua orang dapat memahami pesan yang disampaikan. Penelitian yang dilakukann oleh Zuliyani (2016) menyebutkan bahwa remaja hanya melihat gambar yang tertera pada kemasan rokok dan tidak melihat tentang kandungan yang ada di dalamnya, sedangkan pesan bahaya rokok melalui tayangan televisi tidak diperhatikan remaja karena mereka hanya melihat secara sepintas saja. Penelitian lain juga menyebutkan bahwa pesan yang terkandung dalam kemasan rokok belum dapat meningkatkan pengetahuan terkait bahaya rokok (Widati, 2013). Hal yang sama juga terjadi pada responden penelitian ini. Walaupun mereka sudah tidak asing lagi dengan kemasan rokok ataupun iklan di televisi namun mereka tidak memperhatikan informasi yang ada di dalamnya sehingga hasil pengetahuan responden mengenai bahaya rokok pada kelompok ini masih kurang.

Setelah diberikan media hand lettering, terjadi peningkatan pengetahuan responden. Adanya peningkatan tersebut diperkuat dengan hasil Uji t berpasangan yang menunjukkan adanya perbedaan yang signifikan sebelum dan sesudah diberikan perlakuan. Peningkatan yang terjadi secara signifikan pada kelompok ini kemungkinan dilatar belakangi oleh tingkat pengetahuan awal responden yang masih kurang mengenai bahaya rokok sehingga ketika diberikan media hand lettering mengenai informasi tersebut responden mendapatkan informasi baru. Berdasarkan hasil tersebut maka dapat disimpulkan bahwa hand lettering mampu menyampaikan informasi yang terkandung di dalamnya sehingga dapat meningkatkan pengetahuan responden. Hal tersebut sesuai dengan yang disampaikan oleh Abbey (2016) bahwa pembuatan hand lettering bertujuan untuk menyampaikan informasi. Selain itu penelitian yang dilakukan oleh Dewi (2016) telah membuktikan bahwa hand lettering dapat meningkatkan pengetahuan responden.

\section{Pengetahuan Responden Pada kelompok Kontrol}

Pada kelompok kontrol, responden tidak diberikan media apapun. Namun tetap diberikan pre-test dan post-test untuk mengukur seberapa besar pengaruh intervensi yang diberikan pada penelitian ini. Hasil pre-test pada kelompok ini menunjukan bahwa sebagian besar responden memiliki nilai pengetahuan antara 50-59. Nilai tersebut termasuk dalam kategori kurang dan cukup 
menuurut Nursalam (2008). Hal tersebut juga menunjukan bahwa responden pada kelompok kontrol pernah terpapar informasi mengenai bahaya rokok seperti hasil pre-test pada kelompok poster dan hand lettering.

Setelah dilakukan post-test, tidak terdapat peningkatan antara hasil pre-test dan post-test. Begitu pula saat diUji statistik tidak terdapat perdedaan. Hal tersebut wajar terjadi pada kelompok kontrol karena memang tidak adanya stimulan yang berisi informasi kepada responden sehingga tidak ada pengetahuan baru yang diterima oleh responden. Penggunaan kelompok kontrol dimaksudkan untuk mengetahui seberapa besar pengaruh intervensi atau perlakuan yang diberikan, seperti yang pernah dilakukan oleh Arimurti (2012) dan Haq (2015) di dalam penelitiannya.

\section{Perbedaan Antara Kelompok Poster, Hand Lettering, dan Kelompok Kontrol}

Hasil perbandingan antar kelompok menunjukkan bahwa terdapat perbedaan yang signifikan antara kelompok hand lettering dan kelompok kontrol. Hal yang sama juga terjadi pada perbandingan antara kelompok hand lettering dan poster, sedangkan pada kelompok poster dan kelompok kontrol tidak ada perbedaan.

Adanya perbedaan antara kelompok yang diberikan hand lettering dan poster menunjukkan bahwa nilai yang diperoleh pada kelompok hand lettering jauh lebih tinggi dari pada poster. Hasil penelitian tersebut sejalan dengan penelitian yang dilakukan oleh Dewi (2016) mengenai perbandingan hand lettering dan poster sebagai media promosi kesehatan HIVAIDS yang menyatakan bahwa adanya perbedaan bermakna antara kelompok hand lettering dan poster. Walaupun jika dilihat dari peningkatan nilai mean keduanya sama-sama dapat meningkatkan nilai post-test responden, namun peningkatan yang terjadi pada kelompok poster tidak sebanyak peningkatan pada hand lettering sehingga nilai yang diperoleh responden setelah diberikan poster tidak jauh berbeda dengan post-test pada kelompok yang tidak diberikan media atau kelompok kontrol.

Hasil dalam penelitian ini tentu saja tidak sesuai dari penelitian sebelumnya yang dilakukan Mohamad (2012) dan Kusuma (2014) yang menyebutkan bahwa terdapat perbadaan bermakna antara kelompok poster dan kontrol. Hal tersebut kemungkinan dapat disebabkan oleh pembuatan poster yang digunakan dalam penelitian ini belum memenuhi kriteria poster yang baik. Supriyono (2010) menyebutkan bahwa terdapat beberapa kriteria yang harus dipenuhi dalam pembuatan poster yang baik diantaranya adalah ukuran huruf tidak boleh terlalu kecil, tampilan poster dibuat menarik dan simpel, berisi informasi penting, terdapat elemen penting yang ditonjolkan, informasi penting harus ditonjolkan dengan ukuran, warna, atau kontras, memuat unsur seni, elemen dan huruf visual disusun secara logis, ilustrasi gambar atau foto yang digunakan memiliki unsur unusual agar lebih terlihat, dan huruf poster sebaiknya tebal atau kontras.

Adanya perbedaan yang bermakna pada kelompok hand lettering dengan kontrol dan poster membuktikan bahwa hand lettering mampu dijadikan sebagai alat komunikasi. Hal tersebut sesuai dengan teori yang disampaikan oleh Abbey (2016) bahwa hand lettering digunakan sebagai media komunikasi untuk menyampaikan pesan secara visual kepada pembaca. Selain itu Alessio (2013) menyebutkan bahwa pada zaman dahulu hand lettering telah digunakan di dunia periklanan untuk memberi tahu kepada khalayak mengenai informasi tertentu. Informasi yang disampaikan pada penelitian ini adalah informasi mengenai bahaya rokok. Peneliitian yang dilakukan oleh Gouveia, Ferias, dan Gatto (2009) juga menyebutkan bahwa lettering biasa digunakan untuk menyampaikan informasi, 
peringatan, dan iklan yang terpampang di sudut-sudut kota besar.

\section{Efektifitas Media}

Efektifitas media dilihat dari peningkatan nilai mean (lebih dari sama dengan $10 \%$ ) pada tiap kelompok terkait bahaya rokok. Penentuan efektifitas media tersebut dirujuk berdasarkan penelitian Kusuma (2013) dan Widayani (2015) mengenai efektifitas media.

Hasil penelitian menunjukkan bahwa pemberian media hand lettering efektif dalam meningkatkan pengetahuan responden, namun tidak pada media poster. Walaupun sebenarnya baik hand lettering maupun poster sama-sama dapat meningkatkan pengetahuan, namun peningkatan pada poster yang digunakan dalam penelitian ini dinilai kurang efektif karena memiliki peningkatan nilai mean kurang dari $10 \%$. Nilai mean pada responden yang diberikan media hand lettering lebih tinggi dari pada nilai mean responden yang diberikan poster. Oleh karena itu dapat disimpulkan bahwa hand lettering lebih diminati oleh responden dari pada poster. Saat ini baru terdapat satu penelitian yang meneliti mengenai hand lettering sebagai media promosi kesehatan yaitu penelitian yang dilakukan oleh Dewi (2016). Pada penelitian tersebut juga diperoleh hasil bahwa hand lettering lebih efektif untuk meningkatkan pengetahuan dari pada poster. Perbedaannya adalah jika pada penelitian sebelumnya mengkaji mengenai HIV-AIDS, pada penelitian ini mengkaji mengenai bahaya rokok.

Seperti yang telah kita ketahui bahwa saat ini karya seni hand lettering kembali menjadi trend di kalangan anak muda termasuk remaja (Keesee, 2017). Oleh karena itu responden sebagai remaja lebih tertarik dengan media tersebut sehingga informasi yang disampaikan lebih mudah diterima. Jika hand lettering lebih mengutamakan penggunaan huruf sebagai objek yang disusun menjadi kata-kata sehingga tersusun sebagai desain yang sederhana, poster merupakan konsep visual yang terdiri dari kombinasi garis, warna, dan kata-kata untuk menangkap perhatian pembaca (Benny, 2014). Namun dalam penelitian ini poster yang digunakan kurang diminati oleh responden. Terdapat beberapa kriteria pembuatan poster yang baik menurut Supriyono (2010), salah satunya adalah poster tersebut mampu menarik perhatian pembaca. Pada penelitian ini media poster yang ditampilkan kurang menarik perhatian dan minat baca responden karena memang tulisan yang tercantum ada poster ini terlalu kecil dan desainnya kurang diminati oleh responden sehingga pesan yang disampaikan kurang diterima dan dipahami oleh responden. Seperti yang disampaikan di dalam penelitian Dewi (2016) bahwa desain poster yang kurang sesuai dengan selera responden serta tulisan yang terlalu kecil dapat menghambat masuknya informasi pada responden. Demikian juga penelitiann yang dilakukan oleh Furlan, Kitson, dan Andes (2007) menyebutkan bahwa dalam pembuatan poster harus memperhatikan penggunaan tulisan yang jelas, tidak terlalu banyak, dan ukuran yang sesuai agar dapat dibaca responden. Selain itu jika dilihat dari komposisi warnanya, responden mengatakan bahwa komposisi warna pada kedua media ini kurang menarik. Sanyoto (2005) menyebutkan bahwa warna dapat memberikan pengaruh yang besar terhadap perhatian dan emosi manusia.

Poster dan hand lettering termasuk dalam media visual. Kedua media ini sama-sama dapat digunakan sebagai alat untuk menyampaikan informasi. Wibawanto (2017) menyebutkan bahwa media dapat berfungsi sebagai media pembelajaran. Media visual sebagai media pembelajaran media berperan menjadi alat bantu pendidikan yang memungkinkan seseorang memperoleh pengetahuan, ketrampilan atau sikap. Media visual tidak hanya berperan di dalam pendidikan, namun media juga dapat dimanfaatkan untuk kepentingan kesehatan. Seperti 
halnya pada penelitian ini, penggunakan media tersebut dimanfaatkan sebagai sarana komunikasi untuk menyampaikan pesan kesehatan kepada sasaran (responden) terkait bahaya rokok.

Pada penelitian sebelumya telah dibuktikan bahwa hand lettering efektif digunakan sebagai media promosi kesehatan terkait HIV-AIDS pada remaja (Dewi, 2016). Penelitian membuktikan bahwa hand lettering yang karya seni melukis huruf dapat digunakan sebagai media promosi kesehatan mengenai bahaya rokok, bahkan efektifitasnya dalam meningkatkan pengetahuan lebih tinggi jika dibandingkan dengan efektifitas poster yang digunakan. Notoatmodjo (2007) menyebutkan bahwa pengetahuan merupakan hal yang sangat penting untuk membentuk suatu tindakan. Perilaku yang didasari oleh pengetahuan akan lebih langgeng atau bertahan lama jika dibandingkan dengan perilaku tanpa didasari pengetahuan. Oleh karena itu semakin banyak pengetahuan yang diserap responden diharapkan semakin besar peluang seseorang untuk melakukan dan mempertahankan perilaku kesehatan. Penelitian ini membuktikan bahwa hand lettering mampu memberikan pengetahuan lebih tinggi kepada responden sehingga kedepannya dapat dimanfaatkan sebagai media promosi kesehatan.

\section{SIMPULAN}

Berdasarkan penelitian terdapat perbedaan yang signifikan antara media poster dan hand lettering tersebut. Media hand lettering lebih efektif untuk meningkatkan pengetahuan remaja mengenai bahaya rokok, oleh karena itu hand lettering dapat digunakan sebagai media promosi kesehatan mengenai bahaya rokok pada remaja.

Setelah dilakukan penelitian ini diharapkan media hand lettering dapat digunakan oleh institusi yang setara dengan SMK sebagai alternatif penyampaian informasi mengenai bahaya rokok, karena sudah terUji keefektifitasannya. Hand lettering yang akan digunakan sebagai media promosi kesehatan hendaknya disesuaikan dengan karakterstik sasaran, begitu pula dengan poster. Pembuatan poster juga perlu disesuaikan dengan kriteria pembuatan poster yang baik seperti desain, komponen warna yang menarik dan tulisan yang tidak terlalu kecil sehingga dapat dilihat dengan jelas dan mudah dipahami oleh responden.

\section{DAFTAR PUSTAKA}

Abbey, S. 2016. The ABC of Hand Lettering Indonnesian Edition. Depok: Haru Media

Alessio, J. 2013. Understanding the Difference Between Type and Lettering.

Arimurti, I D. 2012. Pengaruh Pemberian Komik Pendidikan Gizi Seimbang Terhadap Pengetahuan Gizi Siswa Kelas V SDN Sukasari 4 Kota Tangerang Tahun 2012. Skripsi. Universitas Indonesia.

Benny, A P. 2014. Model Desain Sistem Pembelajaran. Jakarta : PT. Dian.

BKKBN. 2009. Buku Penyuluhan Bina Keluarga Remaja: Pengantar Kader tentang Pembinaan Anak Remaja. Jakarta: Direktorat Pengembangan Ketahanan Keluarga Badan Koordinasi Keluarga Berencana Nasional.

Departemen Kesehatan RI. 2013. Riset Kesehatan Dasar. Jakarta: Badan Litbang Kemenkes RI.

Dewi, N S. 2016. Perbandingan Antara Hand Lettering dan Poster sebagai Media Promosi Kesehatan HIV/AIDS pada Remaja. Skripsi. Universitas Airlangga.

Furlan, Y P, Kitson, H, and Andes, C. 2007. Chemistry, Poetry, and Artistic Illustration: An Interdisciplinary Approach to Teaching and Promoting Chemistry. Journal of Chemical education. 84 (10). 
Gouveia, A P S, Farias, P S, dan Gatto, P S. 2009. Letters and Cities: Reading The Urban Environment With The Help of Perception Theories. Sage Journal. 8 (3).

Haq, Z. 2015. Efektifitas Komik Sebagai Media Promosi Kesehatan Anak Usia Sekolah Dasar Tentang Kesehatan Gigi. Skripsi. Universitas Airlangga.

Ikatan Ahli Kesehatan Masyarakat Indonesia. 2013. Indonesia Tobacco Atlas edisi 2013. Tobacco Control Support Center.

Infodatin RI. 2013. Perilaku Merokok Masyarakat Indonesia: Hari Tanpa Tembakau Sedunia. Pusat Data dan Informasi Kementrian kesehatan RI.

Keesee, M. 2017. The Effects of the Hand Lettering Trend.

Kusuma, I A. 2013. Perdedaan Efektiifitas Leaflet dan Poster Produk Komisi Penanggulangan AIDS Kabupaten Jember dalam Perilaku Pencegahan HIV/AIDS. Skripsi. Universitas Jember.

Liviyana, O. 2017. Faktor - Faktor Yang Berhubungan Dengan Praktik Merokok Pada Mahasiswi S1 Universitas Diponegoro Semarang. Jurnal Kesehatan Masyarakat Universitas Diponegoro. Semarang.

Marmot, M and Wilkinson, G R. 2006. Social Determinants of Helath, 2 nd Edition. Oxford University.

Mohamad, F. 2012. Peningkatan Pengetahuan dan Sikap Terhadap Bahaya Rokok Bagi Kesehatan Melalui Poster Dengan Partisipasi Siswa di Kabupaten Gorontalo. Journal of Community Medicine and Publict Health Universitas Gadjah Mada.
Notoatmodjo, S. 2007. Promosi Kesehatan dan Ilmu Perilaku. Jakarta : Rineka Cipta.

Nursalam. 2008. Konsep dan Penerpan Metodologi Penelitian Ilmu Keperawatan. Jakarta: Salemba Medika

Puspromkes Kemenkes RI. 2011. Promosi Kesehatan Komitmen Global dari Ottawa-Jakarta-Helsinki Menuju Rakyat Sehat. Jakarta: Kementrian Kesehatan RI.

Sanyoto, S E. 2005. Dasar-Dasar Tata Rupa dan Desain. Yogyakarta.

Supriyono. 2010. Desain Komunikasi Visual (Teori dan Aplikasi). Yogyakarta: Andi

WHO. 2013. WHO Report on The Global Tobacco Epidemic. Luxembourg: WHOLibrary Catalouging.

Wibawanto, W. 2017. Desain dan Pemrograman Multimedia Pembelajaran Interaktif. Jember : Cerdas Ulet Kreatif.

Widati, S. 2013. Efektivitas Pesan Bahaya Rokok Pada Kemasan Rokok Terhadap Perilaku Merokok Masyarakat Miskin. Jurnal Promkes, 1(2).

Widayani, H P. 2015. Pengembangan Media Permainan Monopoli Sarapan dan

Efektifitasnya Terhadap Peningkatann Pengetahuan Sarapan pada Siswa Kelas V SD N Kalijudan I. Skripsi. Universitas Airlangga.

Zuliyani. 2016. Gambaran Tingkat Pengetahuan Remaja Tentang Bahaya Rokok di SMP 2 Sanden Bantul Yogyakarta. Skripsi. Universitas Muhammadiyah Yogyakarta. 